九州大学学術情報リポジトリ

Kyushu University Institutional Repository

\title{
Synthesis and Anti-Juvenile Hormone Activity of Alkyl 4-(2-Phenoxyalkyloxy) benzoates and Related Compounds
}

Furuta, Kenjiro

Graduate School of Bioresource and Bioenvironmental Sciences, Kyushu University

Shirahashi, Hiromitsu

Graduate School of Bioresource and Bioenvironmental Sciences, Kyushu University

Ashibe, Kiyo

Graduate School of Bioresource and Bioenvironmental Sciences, Kyushu University

Yamashita, Haruma

Graduate School of Bioresource and Bioenvironmental Sciences, Kyushu University

他

https://doi.org/10.5109/9246

出版情報：九州大学大学院農学研究院紀要. 51 (2)，pp. 303-308，2006-10-27. Faculty of Agriculture, Kyushu University

バージョン :

権利関係 : 


\title{
Synthesis and Anti-Juvenile Hormone Activity of Alkyl 4-(2-Phenoxyalkyloxy)benzoates and Related Compounds
}

\author{
Kenjiro FURUTA ${ }^{1}$, Hiromitsu SHIRAHASHI ${ }^{1}$, Kiyo ASHIBE ${ }^{1}$, Haruna YAMASHITA ${ }^{1}$, \\ Masashi NISHIKAWA ${ }^{1}$, Norihiro FUJITA ${ }^{1}$, Naotaka YAMADA \\ and Eiichi KUWANO*
}

\author{
Laboratory of Pesticide Chemistry, Division of Plant Protection, Department of Applied Genetics \\ and Pest Management, Faculty of Agriculture, Kyushu University, \\ Fukuoka 812-8581, Japan \\ (Received June 1, 2006 and accepted July 24, 2006)
}

\begin{abstract}
A number of alkyl 4-(2-phenoxyhexyloxy)benzoates and related compounds were synthesized and evaluated their activity to induce precocious metamorphosis in larvae of the silkworm, which was clearly recognized as a juvenile hormone-deficiency symptom. In the alkyl 4-(2-phenoxyhexyloxy)benzoate series, only the methyl and ethyl esters showed precocious metamorphosis-inducing activity. Replacement of the ester group with an ethylcarbamoyl, butanoyl, nitro or a phenoxy group dramatically decreased or eliminated the activity. Both enantiomers of ethyl 4-(4-methyl-2-phenoxypentyloxy)benzoate (13) were prepared by starting with $\mathrm{L}-$ and $\mathrm{D}-\mathrm{leucine}$. There was no significant difference in precocious metamorphosis-inducing activity between $\mathbf{1 3 R}(+)-$ and $\mathbf{1 3 S}(-)$-enantiomers. Conversion of the 4-ethoxycarbonyl group of $\mathbf{1 3}$ to the corresponding carboxylic acid eliminated the activity, indicating that the methyl or ethyl ester group is indispensable for the activity.
\end{abstract}

\section{INTRODUCTION}

Since juvenile hormone (JH) is involved in a wide range of physiological processes in both developing and mature insects (Riddiford, 1994), compounds that possess anti-JH activity are potentially useful not only as biochemical probes to assist in elucidating the role of $\mathrm{JH}$ in insect development and reproduction, but also as insect growth regulators (Staal, 1986). Several compounds including precocenes (Bowers et al., 1976), fluoromevalonate (Quistad et al., 1981), ethyl 4-[2-(tert-butylcarbonyloxy)butyloxy]benzoate (ETB) (Staal, 1982), dichloroallyl hexanoate (Quistad et al., 1985), 1,5-disubstituted imidazoles (Pratt et al., 1990) and brevioxime (Moya et al., 1997) have so far been found to have anti-JH activity. However, none of the compounds has been developed for practical use in pest control as yet. Among them, ETB is known to be a unique anti-JH agent. It shows anti-JH activity as well as JH activity for the tobacco hornworm, Manduca sexta (Staal, 1982) and the silkworm, Bombyx mori (Kiguchi et al., 1984), depending on the dose applied; low doses of ETB induced precocious metamorphosis, a clear JH-deficiency symptom, but at higher doses only JH-like activity was observed. Riddiford et al. (1983) have reported that ETB acts as a partial JH antagonist at the target tissue of the larval epidermis. No other anti-JH agents with such action have been found to date.

In our previous studies (Ishiguro et al., 2003), we

\footnotetext{
${ }^{1}$ Laboratory of Pesticide Chemistry, Division of Plant Protection, Department of Applied Genetics and Pest Management, Graduate School of Bioresource and Bioenvironmental Sciences, Kyushu University

* Corresponding author (E-mail: ekuwano@agr.kyushu-u.ac.jp)
}

found that ethyl 4-[2-(6-methyl-3-pyridyloxy)butyloxy] benzoate (1), structurally derived from ETB (Fig. 1), showed stronger activity than ETB. Modifications of the ethyl side chain of $\mathbf{1}$ revealed that the butyl (2) and isobutyl (3) groups were optimal for high activity (Fujita et al., 2005). Further structure activity relationship studies on this series of compounds indicated that the phenyl analog $\mathbf{4}$ showed activity comparable to that of $\mathbf{2}$, suggesting that the 6-methyl-3-pyridyl moiety is not significant for activity (Furuta et al., 2006). Conversion of the 4-ethoxycarbonyl group of $\mathbf{2}$ and $\mathbf{4}$ to the corresponding carboxylic acids eliminated the activity, indicating that the ester moiety is responsible for the activity. We therefore synthesized additional analogs in which the ethoxycarbonyl group of $\mathbf{4}$ was modified, and evaluated their activity to induce precocious metamorphosis in B. mori larvae. We also examined the precocious metamorphosis-inducing activity of both optical isomers of ethyl 4-(4-methyl-2-phenoxypentyloxy) benzoate. We report here the structure-activity relationships of new phenyl ether analogs derived from compound 4 .
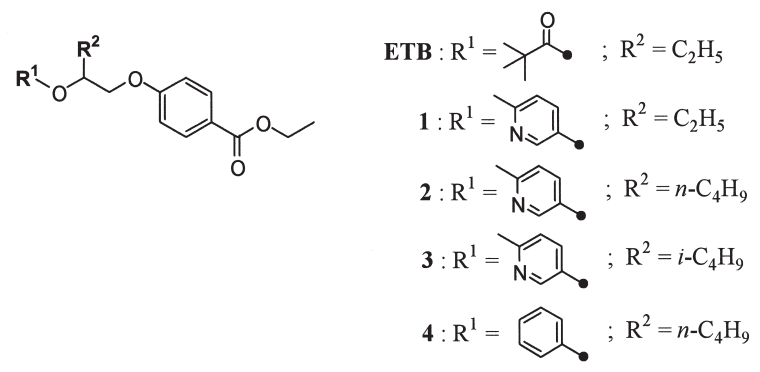

Fig. 1. Structures of ETB and ethyl 4-substituted benzoates. 


\section{MATERIALS AND METHODS}

\section{Synthesis}

The ${ }^{1} \mathrm{H}-\mathrm{NMR}$ spectra were determined with JEOL EX-400 (400 MHz) spectrometer. Optical rotation values were measured with a Union Giken PM-101 polarimeter. HPLC analysis was carried out with a Shimadzu LC-10A equipped with a Shimadzu UV-VIS diode array. All melting points ( $\mathrm{mp}$ ) are uncorrected.

Methyl $(S)$-2-hydroxy-4-methylpentanoate and its enantiomer $(R)$ were prepared from L-leucine and D-leucine respectively according to the method described by Valls et al. (2002). The preparation of a series of phenyl ether analogs (4-12) and optically active $\mathbf{1 3 R}$ is outlined in Fig. 2 (A) and (B), respectively.

(A)
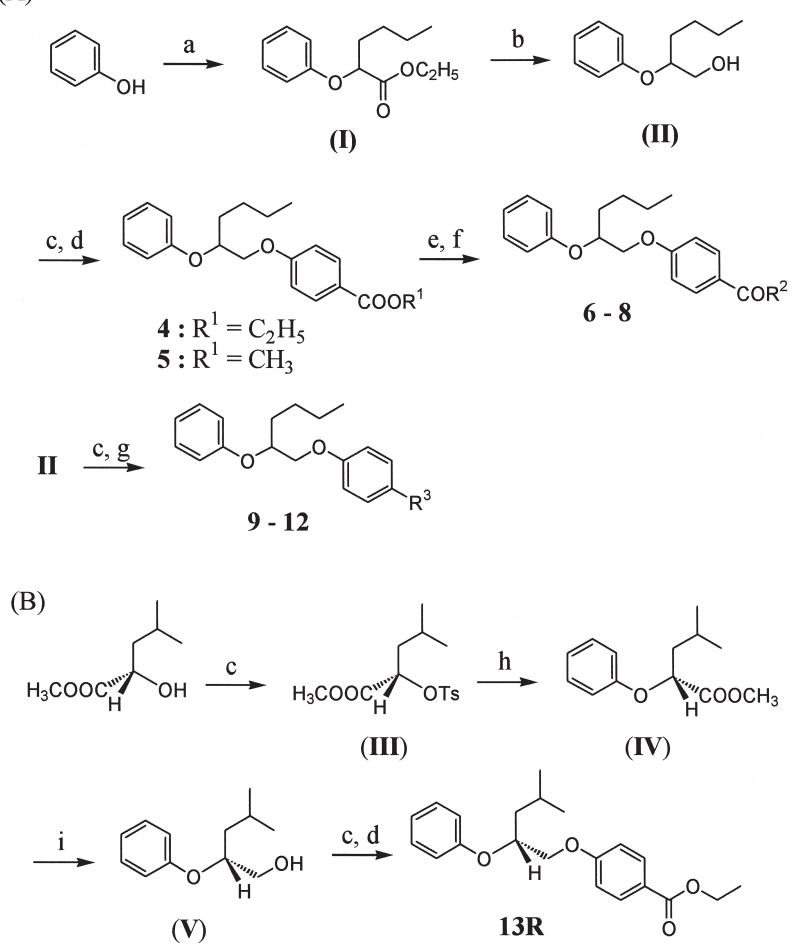

Fig. 2. Synthetic scheme for preparation of (A) ethyl 4-(2-phenoxyhexyloxy)benzoates and related compounds, and (B) ethyl 4-[(R)-4-methyl-2-phenoxypentyloxy]benzoate (13R). (a) ethyl 2-bromohexanoate, $\mathrm{K}_{2} \mathrm{CO}_{3}, \mathrm{DMF}$; (b) $\mathrm{LiAlH}_{4}$, THF; (c) $p$-toluenesulfonyl chloride, triethylamine, THF; (d) ethyl 4-hydroxybenzoate or methyl 4-hydroxybenzoate, $\mathrm{K}_{2} \mathrm{CO}_{3}$, DMF; (e) $\mathrm{NaOH}$, EtOH and $\mathrm{H}_{2} \mathrm{O}$; (f) corresponding alcohol or amine, 4-(N,N-dimethylamino) pyridine, 1-[3-(dimethylamino)propyl]-3-ethylcarbodiimide hydrochloride, $\mathrm{CH}_{2} \mathrm{Cl}_{2}$; (g) 4-substituted phenol, $\mathrm{K}_{2} \mathrm{CO}_{3}$, DMF; (h) phenol, $\mathrm{K}_{2} \mathrm{CO}_{3}, \mathrm{DMF}$; (i) NaBH4, ethanol.

\section{Ethyl 2-phenoxyhexanoate (I)}

A mixture of ethyl 2-bromohexanoate (2.7 g, $12 \mathrm{mmol})$, phenol (1.0 g, $11 \mathrm{mmol})$ and potassium carbonate $(1.7 \mathrm{~g}, 12 \mathrm{mmol})$ in $20 \mathrm{ml}$ of dimethylformamide (DMF) was stirred for $5 \mathrm{hr}$ at room temperature. The mixture was poured into $30 \mathrm{ml}$ of water and the product was extracted with $50 \mathrm{ml}$ of ethyl acetate. The ethyl acetate solution was washed with brine, dried over
$\mathrm{Na}_{2} \mathrm{SO}_{4}$, and concentrated. The residue was purified by column chromatography on silica gel eluting with hexane and ethyl acetate (5:1) to afford $2.4 \mathrm{~g}$ (93\%) of compound $(\mathbf{I}) .{ }^{1} \mathrm{H}-\mathrm{NMR}\left(\mathrm{CDCl}_{3}\right) \delta: 0.93(3 \mathrm{H}, \mathrm{t}, J=$ $\left.7.3 \mathrm{~Hz}, \mathrm{CH}_{3}\right), 1.24\left(3 \mathrm{H}, \mathrm{t}, J=6.8 \mathrm{~Hz}, \mathrm{CH}_{3}\right), 1.35-1.43(2 \mathrm{H}$, $\left.\mathrm{m}, \mathrm{CH}_{2}\right), 1.46-1.54\left(2 \mathrm{H}, \mathrm{m}, \mathrm{CH}_{2}\right), 1.89-1.98(2 \mathrm{H}, \mathrm{m}$, $\left.\mathrm{CH}_{2}\right), 4.30\left(2 \mathrm{H}, \mathrm{q}, J=6.8 \mathrm{~Hz}, \mathrm{CH}_{2}\right), 4.54-4.60(1 \mathrm{H}, \mathrm{m}$, CH), 6.88 (2H, d, $J=8.3 \mathrm{~Hz}$, phenyl), $6.96(1 \mathrm{H}, \mathrm{t}, J=$ $7.3 \mathrm{~Hz}$, phenyl), 7.25-7.29 (2H, m, phenyl).

2-Phenoxy-1-hexanol (II)

A mixture of $\mathbf{I}(2.36 \mathrm{~g}, 10 \mathrm{mmol})$ and lithium aluminum hydride $(0.38 \mathrm{~g}, 10 \mathrm{mmol})$ in $30 \mathrm{ml}$ of tetrahydrofuran (THF) was stirred for $2.5 \mathrm{hr}$ at room temperature. The reaction mixture was quenched with saturated $\mathrm{NH}_{4} \mathrm{Cl}$ solution. After removal of the solvent under reduced pressure, the product was extracted with tert-butyl methyl ether. The ether solution was washed with brine and dried over $\mathrm{Na}_{2} \mathrm{SO}_{4}$. Concentration of the organic layer gave $1.87 \mathrm{~g}(96 \%)$ of $\mathbf{I I} .{ }^{1} \mathrm{H}-\mathrm{NMR}\left(\mathrm{CDCl}_{3}\right)$ $\delta: 0.89\left(3 \mathrm{H}, \mathrm{t}, J=7.3 \mathrm{~Hz}, \mathrm{CH}_{3}\right), 1.24-1.38(4 \mathrm{H}, \mathrm{m}$, $\left.\mathrm{CH}_{2} \mathrm{CH}_{2}\right), 3.71-3.83\left(2 \mathrm{H}, \mathrm{m}, \mathrm{CH}_{2}\right), 4.32-4.38(1 \mathrm{H}, \mathrm{m}$, $\mathrm{CH})$, 6.90-6.98 (3H, m, phenyl), 7.25-7.32 (2H, m, phenyl).

Ethyl 4-(2-phenoxyhexyloxy)benzoate (4)

To a solution of $\mathbf{I I}(1.9 \mathrm{~g}, 9.8 \mathrm{mmol})$ in $30 \mathrm{ml}$ of dichloromethane was added triethylamine (1.46 g, $14 \mathrm{mmol}$ ) and $p$-toluenesulfonyl chloride (2.24 g, $12 \mathrm{mmol}$ ), and the mixture was stirried for $48 \mathrm{hr}$ at room temperature. After removal of the solvent under reduced pressure, the product was extracted with tert-butyl methyl ether. The ether solution was washed with brine, dried over $\mathrm{Na}_{2} \mathrm{SO}_{4}$. Concentration of the solvent gave crude 2-phenoxyhexyl $p$-toluenesulfonate. A mixture of this $p$-toluenesulfonate $(3.17 \mathrm{~g}, 9.5 \mathrm{mmol})$, ethyl 4-hydroxybenzoate $(1.9 \mathrm{~g}, 11 \mathrm{mmol})$ and potassium carbonate $(1.61 \mathrm{~g}, 12 \mathrm{mmol}$ ) in $30 \mathrm{ml}$ of DMF was heated at $90-100^{\circ} \mathrm{C}$ for $8 \mathrm{hr}$. To the mixture was added $30 \mathrm{ml}$ of water and the product was extracted with tert-butyl methyl ether. The ether solution was washed with $1 \mathrm{~N} \mathrm{NaOH}$ solution and brine, dried over $\mathrm{Na}_{2} \mathrm{SO}_{4}$, and concentrated. The residue was purified by column chromatography on silica gel eluting with hexane-ethyl acetate (5:1) to afford $2.73 \mathrm{~g}(84 \%)$ of $\mathbf{4}$ as an oil. ${ }^{1} \mathrm{H}-\mathrm{NMR}\left(\mathrm{CDCl}_{3}\right) \delta: 0.92\left(3 \mathrm{H}, \mathrm{t}, J=7.1 \mathrm{~Hz}, \mathrm{CH}_{3}\right), 1.38$ $\left(3 \mathrm{H}, \mathrm{t}, J=7.2 \mathrm{~Hz}, \mathrm{CH}_{3}\right), 1.39-1.55\left(4 \mathrm{H}, \mathrm{m}, \mathrm{CH}_{2}\right)$, 1.80-1.84 (2H, m, $\left.\mathrm{CH}_{2}\right), 4.09-4.20\left(2 \mathrm{H}, \mathrm{m}, \mathrm{CH}_{2}\right), 4.33$ $\left(2 \mathrm{H}, \mathrm{q}, J=7.2 \mathrm{~Hz}, \mathrm{CH}_{2}\right), 4.56-4.61(1 \mathrm{H}, \mathrm{m}, \mathrm{CH}), 6.89$ ( $2 \mathrm{H}, \mathrm{d}, J=8.7 \mathrm{~Hz}$, phenyl), 6.91-6.97 (2H, m, phenyl), 7.24-7.31 (3H, m, phenyl), $7.97(2 \mathrm{H}, \mathrm{d}, J=8.7 \mathrm{~Hz}$, phenyl).

Compound $\mathbf{5}$ was prepared in the same manner as compound $\mathbf{4}$ with use of methyl 4-hydroxybenzoate instead of ethyl 4-hydroxybenzoate.

Methyl 4-(2-phenoxyhexyloxy)benzoate (5)

${ }^{1} \mathrm{H}-\mathrm{NMR}\left(\mathrm{CDCl}_{3}\right) \delta: 0.89\left(3 \mathrm{H}, \mathrm{t}, J=7.1 \mathrm{~Hz}, \mathrm{CH}_{3}\right)$, 1.24-1.52 (6H, m, 3 $\left.\mathrm{CH}_{2}\right), 2.05-2.11(1 \mathrm{H}, \mathrm{m}, \mathrm{CH}), 2.75$ $\left(2 \mathrm{H}, \mathrm{d}, J=6.9 \mathrm{~Hz}, \mathrm{CH}_{2}\right.$ ), $3.83\left(2 \mathrm{H}, \mathrm{d}, J=5.4 \mathrm{~Hz}, \mathrm{CH}_{2}\right.$ ), $3.88\left(3 \mathrm{H}, \mathrm{s}, \mathrm{CH}_{3}\right), 6.87(2 \mathrm{H}, \mathrm{d}, J=8.8 \mathrm{~Hz}$, phenyl), 7.16-7.28 (5H, m, phenyl), $7.96(2 \mathrm{H}, \mathrm{d}, J=8.8 \mathrm{~Hz}$, phenyl). 
4-(2-Phenoxyhexyloxy)benzoic acid (4-acid)

A mixture of $4(0.48 \mathrm{~g}, 1.4 \mathrm{mmol})$ and $\mathrm{NaOH}(0.24 \mathrm{~g}$, $6 \mathrm{mmol}$ ) in $15 \mathrm{ml}$ of ethanol and $15 \mathrm{ml}$ of water was refluxed for $6 \mathrm{hr}$. After removal of the solvent, the product was extracted with tert-butyl methyl ether. The ether solution was washed with $1 \mathrm{~N} \mathrm{HCl}$ solution and brine, dried over $\mathrm{Na}_{2} \mathrm{SO}_{4}$, and concentrated. The residue was purified by column chromatography on silica gel eluting with hexane and ethyl acetate (1:1) to afford $0.40 \mathrm{~g}(93 \%)$ of $\mathbf{4}$-acid as a solid, $\mathrm{mp} 56.5-58^{\circ} \mathrm{C}$. ${ }^{1} \mathrm{H}-\mathrm{NMR}\left(\mathrm{CDCl}_{3}\right) \delta: 0.92\left(3 \mathrm{H}, \mathrm{t}, J=7.3 \mathrm{~Hz}, \mathrm{CH}_{3}\right)$, $1.32-1.56\left(4 \mathrm{H}, \mathrm{m}, 2 \mathrm{CH}_{2}\right), 1.81-1.87\left(2 \mathrm{H}, \mathrm{m}, \mathrm{CH}_{2}\right)$, 4.11-4.23 (2H, m, $\left.\mathrm{CH}_{2}\right), 4.59-4.64$ (1H, m, CH), 6.93-6.98 (5H, m, phenyl), 7.26-7.31 (2H, m, phenyl), $8.05(2 \mathrm{H}, \mathrm{d}, J=9.3 \mathrm{~Hz}$, phenyl).

Propyl 4-(2-phenoxyhexyloxy)benzoate (6)

To a mixture of $\mathbf{4}$-acid $(0.50 \mathrm{~g}, 1.6 \mathrm{mmol})$, 4-(N,N-dimethylamino)pyridine $(0.05 \mathrm{~g}, 0.41 \mathrm{mmol})$ and 1 -propanol $(0.19 \mathrm{~g}, 3.2 \mathrm{mmol})$ in $30 \mathrm{ml}$ of dichloromethane was added 1-[3-(dimethylamino)propyl]-3-ethylcarbodiimide hydrochloride $(0.35 \mathrm{~g}, 1.8 \mathrm{mmol})$ at $0{ }^{\circ} \mathrm{C}$. After stirring for $30 \mathrm{hr}$ at room temperature, the product was extracted with tert-butyl methyl ether. The ether solution was washed with $1 \mathrm{~N} \mathrm{NaOH}$ solution and brine, dried over $\mathrm{Na}_{2} \mathrm{SO}_{4}$, and concentrated. The residue was purified by column chromatography on silica gel eluting with hexane and ethyl acetate (5:1) to afford $0.56 \mathrm{~g}$ (99\%) of $\mathbf{6}$ as an oil. ${ }^{1} \mathrm{H}-\mathrm{NMR}\left(\mathrm{CDCl}_{3}\right) \delta: 0.92(3 \mathrm{H}, \mathrm{t}$, $\left.J=7.3 \mathrm{~Hz}, \mathrm{CH}_{3}\right), 1.02\left(3 \mathrm{H}, \mathrm{t}, J=7.3 \mathrm{~Hz}, \mathrm{CH}_{3}\right), 1.35-1.43$ $\left(4 \mathrm{H}, \mathrm{m}, 2 \mathrm{CH}_{2}\right), 1.75-1.86\left(4 \mathrm{H}, \mathrm{m}, 2 \mathrm{CH}_{2}\right), 4.09-4.21(2 \mathrm{H}$, $\left.\mathrm{m}, \mathrm{CH}_{2}\right), 4.25\left(2 \mathrm{H}, \mathrm{t}, J=6.4 \mathrm{~Hz}, \mathrm{CH}_{2}\right), 4.58-4.61(1 \mathrm{H}, \mathrm{m}$, $\mathrm{CH})$, 6.89-6.98 (5H, m, phenyl), 7.27-7.30 (2H, m, phenyl), 7.98 ( $2 \mathrm{H}, \mathrm{d}, J=8.8 \mathrm{~Hz}$, phenyl).

Compound $\mathbf{7}$ was similarly synthesized by reaction of 4-acid with 1-butanol.

n-Butyl 4-(2-phenoxyhexyloxy)benzoate (7)

Yield 99\%; oil; 1H-NMR $\left(\mathrm{CDCl}_{3}\right) \delta: 0.91(3 \mathrm{H}, \mathrm{t}, J=$ $\left.7.3 \mathrm{~Hz}, \mathrm{CH}_{3}\right), 0.98\left(3 \mathrm{H}, \mathrm{t}, J=7.3 \mathrm{~Hz}, \mathrm{CH}_{3}\right), 1.33-1.53(6 \mathrm{H}$, $\left.\mathrm{m}, 3 \mathrm{CH}_{2}\right), 1.70-1.77\left(2 \mathrm{H}, \mathrm{m}, \mathrm{CH}_{2}\right), 1.81-1.85(2 \mathrm{H}, \mathrm{m}$, $\left.\mathrm{CH}_{2}\right), 4.09-4.13(1 \mathrm{H}, \mathrm{m}, \mathrm{CH}), 4.17-4.21(1 \mathrm{H}, \mathrm{m}, \mathrm{CH})$, $4.29\left(2 \mathrm{H}, \mathrm{t}, J=6.4 \mathrm{~Hz}, \mathrm{CH}_{2}\right), 4.57-4.60(1 \mathrm{H}, \mathrm{m}, \mathrm{CH})$, 6.88-6.98 (5H, m, phenyl), 7.26-7.31 (2H, m, phenyl), $7.98(2 \mathrm{H}, \mathrm{d}, J=8.8 \mathrm{~Hz}$, phenyl).

\section{N-Ethyl-4-(2-phenoxyhexyloxy)benzamide (8)}

A mixture of ethylamine hydrochloride $(0.14 \mathrm{~g}$, $1.7 \mathrm{mmol})$ and triethylamine $(0.32 \mathrm{~g}, 3.2 \mathrm{mmol})$ in $10 \mathrm{ml}$ of dichloromethane was stirred for $1 \mathrm{hr}$ at room temperature. To the mixture was added 4-acid ( $0.52 \mathrm{~g}$, $1.5 \mathrm{mmol}), 4-(N, N$-dimethylamino $)$ pyridine $(0.03 \mathrm{~g}$, $0.25 \mathrm{mmol}$ ) and $1-[3-($ dimethylamino)propyl]-3-ethylcarbodiimide hydrochloride $(0.37 \mathrm{~g}, 1.9 \mathrm{mmol})$. The mixture was stirred for $2 \mathrm{hr}$ at $0{ }^{\circ} \mathrm{C}$ and then for $20 \mathrm{hr}$ at room temperature. After normal workup, the crude product was purified by column chromatography on silica gel eluting with hexane and ethyl acetate (1:1) to afford $0.56 \mathrm{~g}(100 \%)$ of $\mathbf{8}$ as an oil. ${ }^{1} \mathrm{H}-\mathrm{NMR}\left(\mathrm{CDCl}_{3}\right) \delta$ : $0.92\left(3 \mathrm{H}, \mathrm{t}, J=6.8 \mathrm{~Hz}, \mathrm{CH}_{3}\right), 1.24\left(3 \mathrm{H}, \mathrm{t}, J=6.8 \mathrm{~Hz}, \mathrm{CH}_{3}\right)$, 1.33-1.55 (4H, m, 2CH $\mathrm{CH}_{2}, 1.80-1.86\left(2 \mathrm{H}, \mathrm{m}, \mathrm{CH}_{2}\right), 3.47$ $\left(2 \mathrm{H}, \mathrm{q}, J=6.8 \mathrm{~Hz}, \mathrm{CH}_{2}\right), 4.08-4.11(1 \mathrm{H}, \mathrm{m}, \mathrm{CH})$,
4.15-4.19 (1H, m, CH), 4.56-4.62 (1H, m, CH), $5.99(1 \mathrm{H}$, s, NH), $6.90(2 \mathrm{H}, \mathrm{d}, J=8.3 \mathrm{~Hz}$, phenyl), 6.92-6.98 (3H, m, phenyl), $7.27(2 \mathrm{H}, \mathrm{d}, J=8.3 \mathrm{~Hz}$, phenyl), $7.70(2 \mathrm{H}, \mathrm{d}$, $J=8.3 \mathrm{~Hz}$, phenyl).

Compounds 9-12 were prepared in the same manner as compound $\mathbf{4}$ with use of the corresponding 4-substituted phenol instead of ethyl 4-hydroxybenzoate. The yields were calculated as based on 4-substituted phenol.

1-[4-(2-Phenoxyhexyloxy)phenyl]-1-butanone (9)

Yield 34\%; oil; ${ }^{1} \mathrm{H}-\mathrm{NMR}\left(\mathrm{CDCl}_{3}\right) \delta: 0.92(3 \mathrm{H}, \mathrm{t}, J=$ $\left.7.3 \mathrm{~Hz}, \mathrm{CH}_{3}\right), 1.00\left(3 \mathrm{H}, \mathrm{t}, J=7.3 \mathrm{~Hz}, \mathrm{CH}_{3}\right), 1.35-1.56(4 \mathrm{H}$, $\left.\mathrm{m}, 2 \mathrm{CH}_{2}\right), 1.70-1.86\left(4 \mathrm{H}, \mathrm{m}, 2 \mathrm{CH}_{2}\right), 2.89(2 \mathrm{H}, \mathrm{t}, J=$ $\left.7.3 \mathrm{~Hz}, \mathrm{CH}_{2}\right), 4.10-4.14(1 \mathrm{H}, \mathrm{m}, \mathrm{CH}), 4.18-4.26(1 \mathrm{H}, \mathrm{m}$, $\mathrm{CH}), 4.57-4.63$ (1H, m, CH), 6.91-6.98 (4H, m, phenyl), 7.27-7.31 (3H, m, phenyl), $7.92(2 \mathrm{H}, \mathrm{d}, J=8.3 \mathrm{~Hz}$, phenyl).

4-Nitrophenyl 2-phenoxyhexyl ether (10)

Yield 80\%; oil; ${ }^{1} \mathrm{H}-\mathrm{NMR}\left(\mathrm{CDCl}_{3}\right) \delta: 0.93(3 \mathrm{H}, \mathrm{t}, J=$ $\left.7.3 \mathrm{~Hz}, \mathrm{CH}_{3}\right), 1.34-1.54\left(4 \mathrm{H}, \mathrm{m}, 2 \mathrm{CH}_{2}\right), 1.81-1.86(2 \mathrm{H}, \mathrm{m}$, $\left.\mathrm{CH}_{2}\right), 4.15-4.25\left(2 \mathrm{H}, \mathrm{m}, \mathrm{CH}_{2}\right), 4.59-4.65(1 \mathrm{H}, \mathrm{m}, \mathrm{CH})$, 6.91-6.99 (5H, m, phenyl), 7.27-7.31 (2H, m, phenyl), 8.19 (2H, d, $J=9.3 \mathrm{~Hz}$, phenyl).

4-(Imidazol-1-yl)phenyl 2-phenoxyhexyl ether (11)

Yield 69\%; oil; ${ }^{1} \mathrm{H}-\mathrm{NMR}\left(\mathrm{CDCl}_{3}\right) \delta: 0.93(3 \mathrm{H}, \mathrm{t}, J=$ $\left.7.3 \mathrm{~Hz}, \mathrm{CH}_{3}\right), 1.36-1.53\left(4 \mathrm{H}, \mathrm{m}, 2 \mathrm{CH}_{2}\right), 1.81-1.86(2 \mathrm{H}, \mathrm{m}$, $\left.\mathrm{CH}_{2}\right), 4.08-4.19\left(2 \mathrm{H}, \mathrm{m}, \mathrm{CH}_{2}\right), 4.59-4.62(1 \mathrm{H}, \mathrm{m}, \mathrm{CH})$, 6.95-6.99 (5H, m, phenyl), 7.18-7.31 (6H, m, phenyl, imidazolyl), 7.75 (1H, s, imidazolyl).

4-Phenoxyphenyl 2-phenoxyhexyl ether (12)

Yield 82\%; oil; ${ }^{1} \mathrm{H}-\mathrm{NMR}\left(\mathrm{CDCl}_{3}\right) \delta: 0.92(3 \mathrm{H}, \mathrm{t}, J=$ $\left.7.3 \mathrm{~Hz}, \mathrm{CH}_{3}\right), 1.35-1.46\left(4 \mathrm{H}, \mathrm{m}, 2 \mathrm{CH}_{2}\right), 1.80-1.86(2 \mathrm{H}, \mathrm{m}$, $\left.\mathrm{CH}_{2}\right), 4.02-4.06(1 \mathrm{H}, \mathrm{m}, \mathrm{CH}), 4.11-4.15(1 \mathrm{H}, \mathrm{m}, \mathrm{CH})$, 4.55-4.60 (1H, m, CH), 6.85-7.06 (9H, m, phenyl), 7.26-7.31 (5H, m, phenyl).

Methyl (S)-4-methyl-2-p-toluenesulfonyloxypentanoate (III)

To a solution of methyl (S)-2-hydroxy-4methylpentanoate $(1.0 \mathrm{~g}, 6.8 \mathrm{mmol})$ and triethylamine $(0.83 \mathrm{~g}, 8.2 \mathrm{mmol})$ in $15 \mathrm{ml}$ of dichloromethane was added $p$-toluenesulfonyl chloride (1.6g, $8.2 \mathrm{mmol}$ ). After stirring for $12 \mathrm{hr}$ at room temperature, the product was extracted with ethyl acetate. The organic layer was washed with water and brine, dried over $\mathrm{Na}_{2} \mathrm{SO}_{4}$, and concentrated. The residue was purified by column chromatography on silica gel by eluting with hexane-ethyl acetate (3:1) to afford $1.07 \mathrm{~g}(52 \%)$ of $\mathbf{I I}$ as an oil. ${ }^{1} \mathrm{H}-\mathrm{NMR}\left(\mathrm{CDCl}_{3}\right) \delta: 0.80\left(3 \mathrm{H}, \mathrm{d}, J=6.8 \mathrm{~Hz}, \mathrm{CH}_{3}\right), 0.90$ $\left(3 \mathrm{H}, \mathrm{d}, J=6.8 \mathrm{~Hz}, \mathrm{CH}_{3}\right), 1.52-1.59(1 \mathrm{H}, \mathrm{m}, \mathrm{CH})$, 1.65-1.72 (1H, m, CH), 1.75-1.82 (1H, m, CH), $2.45(3 \mathrm{H}$, $\left.\mathrm{s}, \mathrm{CH}_{3}\right), 3.64\left(3 \mathrm{H}, \mathrm{s}, \mathrm{CH}_{3}\right), 4.86(1 \mathrm{H} . \mathrm{d}, \mathrm{d}, J=3.9,9.3 \mathrm{~Hz}$, CH), $7.33-7.35(2 \mathrm{H}, \mathrm{d}, J=8.3 \mathrm{~Hz}$, phenyl), 7.81-7.83 ( $2 \mathrm{H}, \mathrm{d}, J=8.3 \mathrm{~Hz}$, phenyl).

Methyl (R)-4-methyl-2-phenoxypentanoate (IV)

A suspension of phenol $(0.37 \mathrm{~g}, 3.9 \mathrm{mmol})$ and potassium carbonate $(0.54 \mathrm{~g}, 3.9 \mathrm{mmol})$ in $15 \mathrm{ml}$ of DMSO was stirred for $30 \mathrm{~min}$ at room temperature. To the mixture was added III (1.07 g, $3.6 \mathrm{mmol})$, and the mixture was stirred for $36 \mathrm{hr}$ at room temperature. The product was extracted with ethyl acetate and the ethyl 
acetate solution was washed with $1 \mathrm{~N} \mathrm{NaOH}$ solution and brine, dried over $\mathrm{Na}_{2} \mathrm{SO}_{4}$, and concentrated. The residue was purified by column chromatography on silica gel eluting with hexane and ethyl acetate (3:2) to afford $0.55 \mathrm{~g}(69 \%)$ of $\mathbf{I V}$ as an oil. [a ] ${ }^{19} \mathrm{D} ;+27$ (c1, ethanol). ${ }^{1} \mathrm{H}-\mathrm{NMR}\left(\mathrm{CDCl}_{3}\right) \delta: 0.94\left(3 \mathrm{H}, \mathrm{t}, J=6.8 \mathrm{~Hz}, \mathrm{CH}_{3}\right), 1.00$ $\left(3 \mathrm{H}, \mathrm{d}, J=6.8 \mathrm{~Hz}, \mathrm{CH}_{3}\right), 1.68-1.72(1 \mathrm{H}, \mathrm{m}, \mathrm{CH})$, 1.90-1.99 (2H, m, $\left.\mathrm{CH}_{2}\right), 3.75\left(3 \mathrm{H}, \mathrm{s}, \mathrm{CH}_{3}\right), 4.67$ (1H. d,d, $J=3.9,9.3 \mathrm{~Hz}, \mathrm{CH}), 6.86-6.89(2 \mathrm{H}, \mathrm{d}, J=7.8 \mathrm{~Hz}$, phenyl), 6.96-7.00 (3H, m, phenyl), 7.26-7.30 (2H, m, phenyl).

(R)-4-Methyl-2-phenoxy-1-pentanol (V)

To a solution of $\mathbf{I V}(1.2 \mathrm{~g}, 5.4 \mathrm{mmol})$ in $15 \mathrm{ml}$ of ethanol was added sodium borohydride (0.25g, $6.6 \mathrm{mmol}$ ) and the mixture was stirred for $36 \mathrm{hr}$ at room temperature. After normal workup, the crude product was purified by column chromatography on silica gel eluting with hexane and ethyl acetate (3:1) to afford $0.66 \mathrm{~g}(63 \%)$ of $\mathbf{V}$ as an oil. ${ }^{1} \mathrm{H}-\mathrm{NMR}\left(\mathrm{CDCl}_{3}\right) \delta: 0.90$ $\left(3 \mathrm{H}, \mathrm{t}, J=6.8 \mathrm{~Hz}, \mathrm{CH}_{3}\right), 0.97\left(3 \mathrm{H}, \mathrm{d}, J=6.8 \mathrm{~Hz}, \mathrm{CH}_{3}\right)$, $1.40-1.47$ (1H, m, CH), 1.65-1.81 (2H, m, $\left.\mathrm{CH}_{2}\right)$, 3.67-3.72 (1H, m, CH), 3.82-3.85 (1H, m, CH), 4.44-4.47 (1H, m, CH), 6.94-6.98 (3H, m, phenyl), 7.26-7.31 (2H, m, phenyl).

Ethyl 4-[(R)-4-methyl-2-phenoxypentyloxy]benzoate (13R)

To a solution of $\mathbf{V}(0.65 \mathrm{~g}, 3.4 \mathrm{mmol})$ in $15 \mathrm{ml}$ of dichloromethane was added triethylamine $(0.41 \mathrm{~g}$, $4.1 \mathrm{mmol})$ and $p$-toluenesulfonyl chloride $(0.77 \mathrm{~g}$, $4.1 \mathrm{mmol}$ ). The mixture was stirred for $36 \mathrm{hr}$ at room temperature. The product was extracted with ethyl acetate and the organic layer was washed with water and brine, dried over $\mathrm{Na}_{2} \mathrm{SO}_{4}$. Concentration of the solvent afforded $1.17 \mathrm{~g}$ of crude $(R)-4$-methyl-2-phenoxypentyl $p$-toluenesulfonate. A suspension of ethyl 4-hydroxybenzoate $(0.34 \mathrm{~g}, 2.1 \mathrm{mmol})$ and potassium carbonate $(0.29 \mathrm{~g}, 2.1 \mathrm{mmol})$ in $15 \mathrm{ml}$ of DMF was stirred for $30 \mathrm{~min}$ at room temperature. To the mixture was added above $(R)-4-$ methyl-2-phenoxypentyl $p$-toluenesulfonate $(0.60 \mathrm{~g}, 1.7 \mathrm{mmol})$, and the mixture was heated at $90-100{ }^{\circ} \mathrm{C}$ for $7 \mathrm{hr}$. After normal workup, the crude product was purified by column chromatography on silica gel eluting with hexane and ethyl acetate (4:1) to afford $0.49 \mathrm{~g}(80 \%)$ of $\mathbf{1 3 R}$ as an oil. [a ] ${ }^{19} \mathrm{D} ;+27$ (c1, ethanol). ${ }^{1} \mathrm{H}-\mathrm{NMR}\left(\mathrm{CDCl}_{3}\right) \delta: 0.94(3 \mathrm{H}, \mathrm{t}, J=$ $\left.6.8 \mathrm{~Hz}, \mathrm{CH}_{3}\right), 1.00\left(3 \mathrm{H}, \mathrm{d}, J=6.8 \mathrm{~Hz}, \mathrm{CH}_{3}\right), 1.37(3 \mathrm{H}, \mathrm{t}$, $\left.J=7.3 \mathrm{~Hz}, \mathrm{CH}_{3}\right), 1.57-1.65(1 \mathrm{H}, \mathrm{m}, \mathrm{CH}), 1.78-1.92(2 \mathrm{H}$, $\left.\mathrm{m}, \mathrm{CH}_{2}\right), 4.07-4.11(1 \mathrm{H}, \mathrm{m}, \mathrm{CH}), 4.14-4.18(1 \mathrm{H}, \mathrm{m}, \mathrm{CH})$, $4.34\left(2 \mathrm{H}, \mathrm{q}, J=7.3 \mathrm{~Hz}, \mathrm{CH}_{2}\right), 4.68-4.70(1 \mathrm{H}, \mathrm{m}, \mathrm{CH})$, $6.89(2 \mathrm{H}, \mathrm{d}, J=7.3 \mathrm{~Hz}$, phenyl), $6.90(2 \mathrm{H}, \mathrm{d}, J=8.8 \mathrm{~Hz}$, phenyl), 7.27-7.31 (3H, m, phenyl), 7.97 (2H, d, $J=$ $8.8 \mathrm{~Hz}$, phenyl). The optical purity was $63 \%$ ee by HPLC analysis under following conditions: Column; CHIRALPAC OD-H (4.6× $250 \mathrm{~mm}$, Daicel Chemical Industry Co.), Mobile phase; hexane-2-propanol (99:1), Detection; UV 260 nm, Flow rate; $1 \mathrm{ml} / \mathrm{min}$.

Compound $\mathbf{1 3 S}$ was prepared in the same manner as 13R with use of methyl (R)-2-hydroxy-4methylpentanoate instead of $(S)$-isomer. Compound 13S: oil, [a ] ${ }^{19} \mathrm{D} ;-27$ ( $c 1$, ethanol), Optical purity; 59\% ee. The ${ }^{1} \mathrm{H}-\mathrm{NMR}$ spectrum of $\mathbf{1 3 S}$ was completely consistent with that of $\mathbf{1 3 R}$.

Methyl 4-(4-methyl-2-phenoxypentyloxy)benzoate (14) was prepared in the same manner as compound $\mathbf{4}$ with use of ethyl 2-bromo-4-methylpentanoate and methyl 4-hydroxybenzoate instead of ethyl 2-bromohexanoate and ethyl 4-hydroxybenzoate, respectively. ${ }^{1} \mathrm{H}-\mathrm{NMR}\left(\mathrm{CDCl}_{3}\right) \delta: 0.94\left(3 \mathrm{H}, \mathrm{d}, J=6.4 \mathrm{~Hz}, \mathrm{CH}_{3}\right), 1.00$ $\left(3 \mathrm{H}, \mathrm{d}, J=6.8 \mathrm{~Hz}, \mathrm{CH}_{3}\right), 1.58-1.83(1 \mathrm{H}, \mathrm{m}, \mathrm{CH})$, 1.85-1.91 (2H, m, $\left.\mathrm{CH}_{2}\right), 3.88\left(3 \mathrm{H}, \mathrm{s}, \mathrm{CH}_{3}\right), 4.07-4.11$ $(1 \mathrm{H}, \mathrm{m}, \mathrm{CH}), 4.15-4.18(1 \mathrm{H}, \mathrm{m}, \mathrm{CH}), 4.67-4.70(1 \mathrm{H}, \mathrm{m}$, $\mathrm{CH}), 6.89(2 \mathrm{H}, \mathrm{d}, J=8.8 \mathrm{~Hz}$, phenyl), 6.94-6.99 (3H, m, phenyl), 7.26-7.30 (2H, m, phenyl), 7.97 (2H, d, $J=$ $8.8 \mathrm{~Hz}$, phenyl).

4-(4-Methyl-2-phenoxypentyloxy)benzoic acid (14-acid) was prepared by the alkaline hydrolysis of $\mathbf{1 4}$ in the same way as described in 4-acid. Mp $96-98^{\circ} \mathrm{C}$. 1H-NMR $\left(\mathrm{CDCl}_{3}\right) \delta: 0.95\left(3 \mathrm{H}, \mathrm{d}, J=6.4 \mathrm{~Hz}, \mathrm{CH}_{3}\right), 1.01$ $\left(3 \mathrm{H}, \mathrm{d}, J=6.8 \mathrm{~Hz}, \mathrm{CH}_{3}\right), 1.58-1.65(1 \mathrm{H}, \mathrm{m}, \mathrm{CH})$, $1.81-1.93\left(2 \mathrm{H}, \mathrm{m}, \mathrm{CH}_{2}\right), 4.09-4.20\left(2 \mathrm{H}, \mathrm{m}, \mathrm{CH}_{2}\right)$, 4.66-4.72 (1H, m, CH), 6.91-6.99 (5H, m, phenyl), 7.25-7.31 (2H, m, phenyl), 8.03-8.05 (2H, m, phenyl).

\section{Biological evaluation}

B. mori (Shunrei $\times$ Shougetsu) larvae were reared on artificial diet as previously reported (Yoshida et al., 2000). Test compounds in acetone solution ( $1 \sim$ $4 \mu \mathrm{l} /$ larva) were topically applied to the dorsal abdomen of $24 \mathrm{hr}$-old $3 \mathrm{rd}$ instar and newly molted 4 th instar larvae. Compounds $\mathbf{1 4}$ and 14-acid were mixed with the artificial diet at concentrations of 50 and $200 \mathrm{ppm}$ according to the procedure reported (Asano et al., 1984). The diet containing test compound was administered for the first $48 \mathrm{hr}$ to newly molted 3rd and 4th instar larvae. Twenty larvae were used for each dose. The activity of compounds was evaluated by the induction of precocious metamorphosis: spinning a cocoon and subsequent pupation or formation of larval-pupal intermediates from the 4th instar (penultimate) larval period.

\section{RESULTS AND DISCISSION}

Table 1 shows precocious metmorphosis-inducing activity of alkyl 4-(2-phenoxyhexyloxy)benzoates and related compounds against 3rd and 4th instar larvae of B. mori. In contrast to ETB (Kiguchi et al., 1984), the activity of the ethyl ester $\mathbf{4}$ to induce precocious metamorphosis correlated with the applied dose when applied to 3rd instar larvae. The methyl ester $\mathbf{5}$ showed somewhat higher activity than $\mathbf{4}$. In these cases, precocious metamorphosis was always caused in the 4th larval stage. None of the treated 3rd instar larvae metamorphosed into precocious pupae in the same larval stage by a single topical application of these compounds. A dramatic decrease in activity was observed in changing from ethyl to $n$-propyl (6) and $n$-butyl (7) ester, indicating that the size of the alkyl group in the ester moiety is significant for activity. Replacement of the ethoxycarbonyl group with the ethylcarbamoyl substituent (8) led 
Table 1. Precocious metamorphosis-inducing activity of alkyl 4-(2-phenoxyhexyloxy)benzoates and related compounds against $3 \mathrm{rd}$ and 4 th instar larvae of $B$. mori

\begin{tabular}{|c|c|c|c|c|c|c|}
\hline \multirow[b]{3}{*}{ No } & \multirow[b]{3}{*}{ ( $\mu \mathrm{g} /$ larva) } & \multicolumn{5}{|c|}{ Precocious metamorphosis (\%) } \\
\hline & & \multicolumn{3}{|c|}{ 3rd instar } & \multicolumn{2}{|c|}{ 4th instar } \\
\hline & & 1 & 10 & 40 & 1 & 10 \\
\hline 4 & $\mathrm{COOC}_{2} \mathrm{H}_{5}$ & 32 & 66 & 70 & 0 & 0 \\
\hline 5 & $\mathrm{COOCH}_{3}$ & 70 & 97 & 95 & NT & 0 \\
\hline 6 & $\mathrm{COO}-n-\mathrm{C}_{3} \mathrm{H}_{7}$ & 0 & 0 & NT & 0 & 0 \\
\hline 7 & $\mathrm{COO}-n-\mathrm{C}_{4} \mathrm{H}_{9}$ & 0 & 0 & NT & 0 & 0 \\
\hline 8 & $\mathrm{CONHC}_{2} \mathrm{H}_{5}$ & 0 & 0 & 15 & 0 & 0 \\
\hline 9 & $\mathrm{COC}_{3} \mathrm{H}_{7}$ & 0 & 0 & NT & 0 & 0 \\
\hline 10 & $\mathrm{NO}_{2}$ & 0 & 0 & NT & 0 & 0 \\
\hline 11 & & 5 & 5 & NT & 0 & 0 \\
\hline 12 & & 0 & 0 & NT & 0 & 0 \\
\hline
\end{tabular}

NT: not tested

to a drastic decrease in precocious metamorphosis-inducing activity. The butanone analog $\mathbf{9}$ did not show any activity at 1 and $10 \mu \mathrm{g}$. Introduction of a stronger electron-withdrawing nitro group on the benzene ring (10) eliminated the activity at $10 \mu \mathrm{g}$. The imidazolyl analog 11 slightly induced precocious pupation. The phenoxy analog $\mathbf{1 2}$ had little activity. These results indicate that in this series of compounds the ethyl and methyl ester groups play an important role for activity. None of the compounds tested showed precocious-metamorphosis inducing activity when applied to newly molted 4th instar larvae.

As previously reported (Fujita et al., 2005), in the ethyl 4-[2-(6-methyl-3-pyridyl)alkyloxy]benzoate series, the isobutyl analog $\mathbf{3}$ showed somewhat higher activity than the butyl analog $\mathbf{2}$ against 3rd instar larvae. Additionally, in contrast to compound $\mathbf{2}$, compound $\mathbf{3}$ induced precocious pupation when applied to 4th instar larvae, though very low activity. We therefore synthesized both enantiomers of ethyl 4-(4-methyl-2phenoxypentyloxy)benzoate (13) by starting with Land D-leucine, and examined their activity to induce precocious metamorphosis (Table 2). Although the enantiomeric purities of $\mathbf{1 3 R}(+)(63 \%$ ee) and $\mathbf{1 3 S}(-)$

Table 2. Precocious metamorphosis-inducing activity of ethyl or methyl 4-(4-methyl-2-phenoxypentyl)benzoate against 3rd and 4th instar larvae of $B$. mori

\begin{tabular}{|c|c|c|c|c|c|c|c|}
\hline \multirow[b]{3}{*}{ No } & \multirow{3}{*}{\multicolumn{2}{|c|}{$\mathbf{R} \quad 0$ ( $\mu \mathrm{g} /$ larva $)$}} & \multicolumn{5}{|c|}{ Precocious metamorphosis (\%) } \\
\hline & & & \multicolumn{3}{|c|}{ 3rd instar } & \multicolumn{2}{|c|}{ 4th instar } \\
\hline & & & 1 & 10 & 40 & 1 & 10 \\
\hline \multirow{3}{*}{13} & \multirow{3}{*}{$\mathrm{C}_{2} \mathrm{H}_{5}$} & racemi & 0 & 50 & 95 & 5 & 5 \\
\hline & & $R(+)$ & 7 & 45 & 79 & 15 & 20 \\
\hline & & $\mathrm{S}(-)$ & 20 & 60 & 85 & 15 & 0 \\
\hline 14 & $\mathrm{CH}_{3}$ & racemi & 25 & 70 & 80 & 0 & 15 \\
\hline
\end{tabular}

(59\% ee) were not so high, these compounds were assumed to be satisfactory for testing as anti-JH agents to determine their potency relative to the racemic compound. There was no significant difference in precocious metamorphosis-inducing activity between 13R $(+)$ and $\mathbf{1 3 S}(-)$-enantiomers. The activity of both enantiomers against 3rd instar larvae correlated with the applied dose. Similar results have been obtained previously in the optical isomers of the isobutyl analog $\mathbf{3}$ (Fujita et al., 2005). Thus, it was found that the stereochemistry of the isobutyl analogs $\mathbf{3}$ and $\mathbf{1 3}$ did not influence the precocious metamorphosis-inducing activity. It is noteworthy that compound $\mathbf{1 3}$ as well as compound $\mathbf{3}$ slightly induced precocious metamorphosis when applied to 4th instar larvae. The methyl ester ana$\log \mathbf{1 4}$ had almost the same activity as that of the ethyl ester 13.

We have already reported (Fujita et al., 2005) that the ethyl ester of the butyl analog $\mathbf{2}$ was indispensable for activity, because the corresponding benzoic acid, which might be produced by hydrolysis of $\mathbf{2}$ in the larval hemolymph, showed no activity. To see whether the ester portion of $\mathbf{1 3}$ or $\mathbf{1 4}$ was necessary for activity, we tested the activity of the corresponding acid (14-acid) as well. Since compound 14-acid did not show any activity by topical application, presumably due to the low permeability of 14-acid through the larval cuticle, we compared the activity of the methyl ester $\mathbf{1 4}$ and 14-acid by dietary administration (Table 3). Compound $\mathbf{1 4}$ induced precocious metamorphosis by dietary administration as well as topical application when applied to 3rd instar larvae, while 14-acid did not show activity at 50 and $200 \mathrm{ppm}$. This result indicates that the ester group of the compounds $\mathbf{1 3}$ and $\mathbf{1 4}$ is responsible for the activity, similar to the results obtained for compound $\mathbf{2}$. Neither compound $\mathbf{1 4}$ nor 14-acid induce precocious pupation by dietary administration against newly molted 4th instar larvae.

In conclusion, we have found that in the alkyl 4-(2-phenoxyhexyloxy)benzoate series only methyl and

Table 3. Precocious metamorphosis-inducing activity of compounds 14 and 14-acid by dietary administration against 3rd and 4th instar larvae of $B$. mori

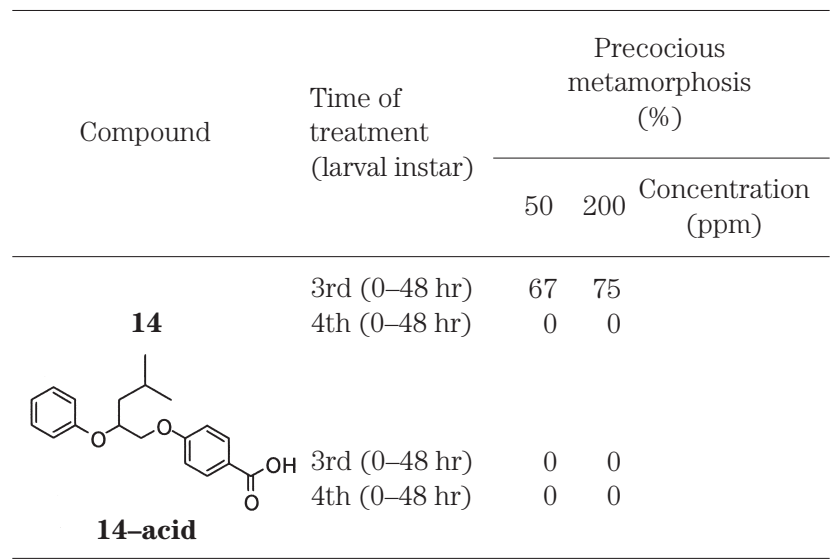

The diet containing compounds was administered for the first $48 \mathrm{hr}$ to newly molted 3rd and 4th instar larvae. 
ethyl esters showed precocious metamorphosis-inducing activity against 3rd instar larvae of $B$. mori. The isobutyl analogs $\mathbf{1 3}$ and $\mathbf{1 4}$ as well as compound $\mathbf{2}$ induced precocious pupation when applied to newly molted 4th instar. Based on these results, further investigations on the structure-activity relationships of this series of compounds are in progress.

\section{ACKNOWLEDGMENTS}

We thank Ms. Yuko Sakaki for her technical support. This work was supported by a grant-in-aid to E. K. for scientific research (no. 17208007) from the Ministry of Education, Culture, Sports, Science, and Technology of Japan.

\section{REFERENCES}

Asano, S., E. Kuwano and M. Eto 1984 Anti-juvenile hormone activity of 1-citronellyl-5-phenylimidazole in the 3rd instar silkworm, Bombyx mori L. Appl. Ent. Zool., 19: 212-220

Bowers, W. S., T. Ohta, J. S. Cleere and P. A. Marsella 1976 Discovery of insect anti-juvenile hormones in plants. Science, 193: $542-547$

Fujita, N., K. Furuta, H. Shirahashi, S. Hong, T. Shiotsuki and E. Kuwano 2005 Synthesis and anti-juvenile hormone activity of ethyl 4-[2-(6-methyl-3-pyridyloxy)alkyloxy]benzoates. J. Pesticide Sci., 30: 192-198

Furuta, K., H. Shirahashi, H. Yamashita, K. Ashibe and E. Kuwano 2006 Synthesis and anti-juvenile hormone activity of ethyl 4-(2-aryloxyhexyl)benzoates. Biosci. Biotechnol. Biochem., 70: $746-748$

Ishiguro, H., N. Fujita, I.-H. Kim, T. Shiotsuki and E. Kuwano 2003 Ethyl 4-[2-(6-methyl-3-pyridyloxy)butyloxy]benzoate, a novel anti-juvenile hormone agent. Biosci. Biotechnol. Biochem., 67: 2045-2047

Kiguchi, K., T. Mori and H. Akai 1984 Effects of anti-juvenile hormone "ETB" on the development and metamorphosis of the silkworm, Bombyx mori. J. Insect Physiol., 30: 499-506

Moya, P., M. Castillo, E. Primo-Yufera, F. Couillaud, R. Martinez-Mariez, M.-D. Garcera, M. A. Miranda, J. Primo and R. Martinez-Pardo 1997 Brevioxime: A new juvenile hormone biosynthesis inhibitor isolated from Penicillium brevicompactum. J. Ogr. Chem., 62: 8544-8545

Pratt, G. E., E. Kuwano, D. E. Farnsworth and R. Feyereisen 1990 Structure/activity studies on 1,5-disubstituted imidazoles as inhibitors of juvenile hormone biosynthesis in isolated corpora allata of the cockroach, Diploptera punctata. Pestic. Biochem. Physiol., 38: 223-230

Quistad, G. B., D. C. Cerf, D. A. Schooley and G. B. Staal 1981 Fluoromevalonate acts as an inhibitor of insect juvenile hormone biosynthesis. Science, 289: 176-177

Quistad, G. B., D. C. Cerf, S. J. Kramer, J. B. Bergot and D. A. Schooley 1985 Design of novel anti juvenile hormones: Allylic alcohol derivatives. J. Agric. Food Chem., 33: 47-50

Riddiford, L. M., C. R. Roseland, S. Thalberg and A. T. Curtis 1983 Actions of two juvenile hormone antagonists on lepidopteran epidermis. J. Insect Physiol., 29: 281-286

Riddiford, L. M. 1994 Cellular and molecular actions of juvenile hormone 1. General considerations and premetamorphic actions. Adv. Insect Physiol., 24: 213-274

Staal, G. B. 1982 Insect control with growth regulation interfering with the endocrine system. Entomol. Exp. Appl., 31: 15-23

Staal, G. B. 1986 Anti juvenile hormone agents. Ann. Rev. Entomol., 31: 391-429

Valls, N., M. Vallribera, M. Lopez-Canet and J. Bonjoch 2002 Synthesis of microcin SF608. J. Org. Chem., 67: 4945-4950

Yoshida, T., T. Shiotsuki and E. Kuwano 2000 Synthesis and precocious metamorphosis-inducing activity of 3-(1-alkenyl) pyridines. J. Pesticide Sci., 25: 253-258 